OPEN ACCESS

Citation: Saibeh K. et al. (2020) Studies on Schismatoglottideae (Araceae) of Borneo LXIX: Schismatoglottis imbakensis, a new species of the Patentinervia Complex from ultramafic rocks, Sabah. Webbia. Journal of Plant Taxonomy and Geography 75(1): 105-110. doi: 10.36253/jopt-7945

Received: January 29, 2020

Accepted: May 5, 2020

Published: June 30, 2020

Copyright: (c) 2020 Kartini Saibeh, Peter C. Boyce, Wong Sin Yeng. This is an open access, peer-reviewed article published by Firenze University Press (http://www.fupress.com/webbia) and distributed under the terms of the Creative Commons Attribution License, which permits unrestricted use, distribution, and reproduction in any medium, provided the original author and source are credited.

Data Availability Statement: All relevant data are within the paper and its Supporting Information files.

Competing Interests: The Author(s) declare(s) no conflict of interest.

Funding: This is part of on-going research project grant GKP00010ST-2016.

Editor: Thomas B. Croat

\section{Studies on Schismatoglottideae (Araceae) of Borneo LXIX: Schismatoglottis imbakensis, a new species of the Patentinervia Complex from ultramafic rocks, Sabah}

\author{
Kartini Saibeh ${ }^{1, *}$, Peter C. Boyce ${ }^{2}$, Wong Sin Yeng ${ }^{3,4}$ \\ ${ }^{1}$ Faculty of Sustainable Agriculture, Universiti Malaysia Sabah, 90509, Sandakan, Sabah, \\ Malaysia \\ ${ }^{2}$ Department Biologie I, Systematische Botanik und Mykologie, Ludwig-Maximilians- \\ Universität München, München, Germany \\ ${ }^{3}$ Institute of Biodiversity and Environmental Conservation, Universiti Malaysia Sarawak \\ 94300 Kota Samarahan, Sarawak, Malaysia \\ ${ }^{4}$ Harvard University Herbaria, 22 Divinity Avenue, Cambridge, MA 02138, USA \\ *Corresponding author. E-mail: k_saibeh@ums.edu.my
}

Abstract. Schismatoglottis imbakensis is described as a new species of the Schismatoglottis Patentinervia Clade from forested ultramafic rocks, and compared with S. retinervia Furtado, the only the species for the clade yet described from Sabah.

Keywords: Schismatoglottis, Patentinervia clade, Sabah, Borneo.

\section{INTRODUCTION}

The Schismatoglottis Patentinervia Clade is entirely Bornean (Wong et. al., 2017, 2019), comprising small mesophytic herbs with highly distinctive lanceolate to oblong-elliptic to narrowly obovate leaf blades lacking posterior lobes, and with ladder-like rather closely spaced numerous primary lateral veins diverging from the mid-rib at about $90^{\circ}$. At present the clade comprises 11 described species, 8 of which have been described in the past three years (Boyce 2017; Wong et al. 2017, 2018, 2019). Until now, only one species of the Patentinervia Clade has been recorded from Sabah, Schismatoglottis retinervia Furtado (1935), restricted to the vicinity of Kinabalu between 1000 and $1600 \mathrm{~m}$ asl on granite.

During a Borneo Geographic Scientific Expedition organised by Universiti Malaysia Sabah (UMS) and the Sabah Foundation to the Sungai Kangkawat, Imbak Canyon Conservation Area (ICCA), the first author encountered a small colony of a highly distinctive Schismatoglottis with venation suggesting a species of the Patentinervia Clade. At the time of discovery the plants were sterile although their distinctive morphology and occurrence on 
ultrabasic rocks let us to suspect they represented an undescribed species. Subsequently the plant flowered in the living collection of UMS revealing the plant to be a taxonomic novelty of the Patentinervia Clade, and furthermore the forst species of the clade recorded from ultramafic rocks. It is described here as Schismatoglottis imbakensis.

The Imbak Canyon Conservation Area is located immediately to the north of Maliau Basin Conservation Area in central Sabah. The canyon of Cretacoues to Paleogene deep water sediments with ultramafic outcrops encompasses a range of lowland to hill forest habitats within a $10 \mathrm{~km}$ long valley (at about $250 \mathrm{~m}$ asl.), hemmed in on three sides by sandstone ridges up to $1000 \mathrm{~m}$ asl. (Oldfield 2014). The Kangkawat Research Station is located at the eastern part of the canyon near to the Sungai Kangkawat river. And close by Cretaceous outcroppings of ultramafic Harzburgite and Serpentinite.

Dimensions in the descriptions are from fertile (i.e., mature) plants. Seedlings have overall smaller measurements. Geological occurrences in this paper are verified with Tate (2001).

Schismatoglottis imbakensis Kartini, S. Y. Wong \& P. C. Boyce, sp. nov.

Type: Malaysian Borneo. Sabah. East Coast Division, Telupid, Imbak Canyon Conservation Area, Sungai Kangkawat, 1 Oct 2018, 5 $5^{\circ} 4.62^{\prime \prime} \mathrm{N} 117^{\circ} 3^{\prime} 20.10^{\prime \prime} \mathrm{E}$, ca 260 $\mathrm{m}$ asl, (holotype BORH $2705+$ spirit). (Figures 1 and $3 \mathrm{~A})$.

\section{Diagnosis}

Schismatoglottis imbakensis is distinguished from S. retinervia, the only other species of the Patentinervia clade occurring in Sabah, by the plant glabrous (vs petioles and abaxial midribs puberulous), by the naked sterile interstice of the spadix equalling the pistillate floret zone (vs naked sterile interstice hardly developed), by the deep green pistils with the stigma about half the width of the ovary (vas pistils dirty pale green with the stigma almost equalling the ovary width), by the staminate florets somewhat laxly arranged and the stamens readily discernible (vs staminate florets very densely packed and individual stamens scarcely distinguishable). Schismatoglottis imbakensis is distinguished from S. pichinensis and S. puncakborneensis, the other two Patentinervia clade species with a long naked sterile interstice, by large rhomboidal cream interpistillar staminodes (vs interpistillar staminodes lorate or if rhomboidal then small and white), the large, laxly arranged stamens (vs small and congensted), and sharply pointed (vs blunt) spadix appendix.

\section{Description}

Small, colony-forming mesophytic herb to $\mathrm{ca} 10 \mathrm{~cm}$ tall. Stem epigeal, erect to sprawling, rather elongate, to c. 50 $\mathrm{cm}$ long, c. $0.5 \mathrm{~cm}$ diam., decumbent portions tending to root along their length, modules pleionanthic, internodes $0.2-1 \mathrm{~cm}$ long, green. Leaves many together along distal parts of stem and tending to become clustered at apex; petiole 3-4 cm long, D-shaped in cross-section, sheathing in lower $1 / 2-2 / 3$, pale green, glabrous; petiolar sheath wings fully attached to petiole, rather wide and tending to be flat, membranous, long-persistent; leaf blades glossy metallic dark green adaxially, much paler abaxially, oblong-elliptic, $4-6 \mathrm{~cm}$ long $\times 1.5-2 \mathrm{~cm}$ wide, base cuneate, apex blunt with a brief tubular mucro ca 0.5 $\mathrm{mm}$ long; midrib abaxially prominent, adaxially slightly impressed into blade; primary lateral veins about 9 on each side, mostly alternating with barely lesser interprimaries, diverging at $80-90^{\circ}$ from midrib, then gradually and evenly curving up to meet margin, abaxially rather prominent; interprimaries almost indistinguishable from primaries, occurring more or less equally between them; secondary venation mostly arising from midrib, occasionally from base of primary veins; tertiary venation abaxially forming a faint tessellate reticulum. Inflorescence solitary; peduncle to $\mathrm{c}$. $1 \mathrm{~cm}$ long, more often peduncle and part of lower spathe obscured by leaf bases, pale green. Spathe 3-3.5 cm long; lower spathe c. $1.5 \mathrm{~cm}$ long, ovoid, differentiated from limb by a marked constriction, semi glossy pale green; spathe limb ovate, c. $1.5-2 \mathrm{~cm}$ long, mucronate for $0.5-1 \mathrm{~mm}$, opening slightly at pistillate anthesis, white at anthesis, later darkening and rottingdeciduous. Spadix sub-equalling spathe, sessile; pistillate floret zone c. $7 \mathrm{~mm}$ long, conoid; pistils crowded, subglobose, $1 \mathrm{~mm}$ diam., dark green; stigma sessile, button-like, subequalling diameter of ovary, pale green, conspicuously papillate at anthesis; interpistillar staminodes confined to a ring at base of pistillate zone, rhomboid, glossy cream, ca $1 \mathrm{~mm}$ across; sterile interstice attenuate, naked ca 3 $\mathrm{mm}$ long, pale green; staminate zone rather stoutly obconoid, ca $8 \mathrm{~mm}$ long, $2.5 \mathrm{~mm}$ diam. at base, $6 \mathrm{~mm}$ diam. distally; stamens rather lax, dumbbell-shaped, truncate with connective flat between thecae; pores joined across the anther by a narrow deep slit, each with a heavily thickened rim, dull white; appendix wider than the widest part of the with staminate flower zone, stoutly conic, blunt, ca $1.5 \mathrm{~cm}$ long; appendix staminodes composed of irregularly rhomboidal to polygonal-shaped, truncate staminodes c. $1 \mathrm{~mm}$ diam., creamy white. Fruiting spathe urceolate, ca $1 \mathrm{~cm}$ long, mid-green. 


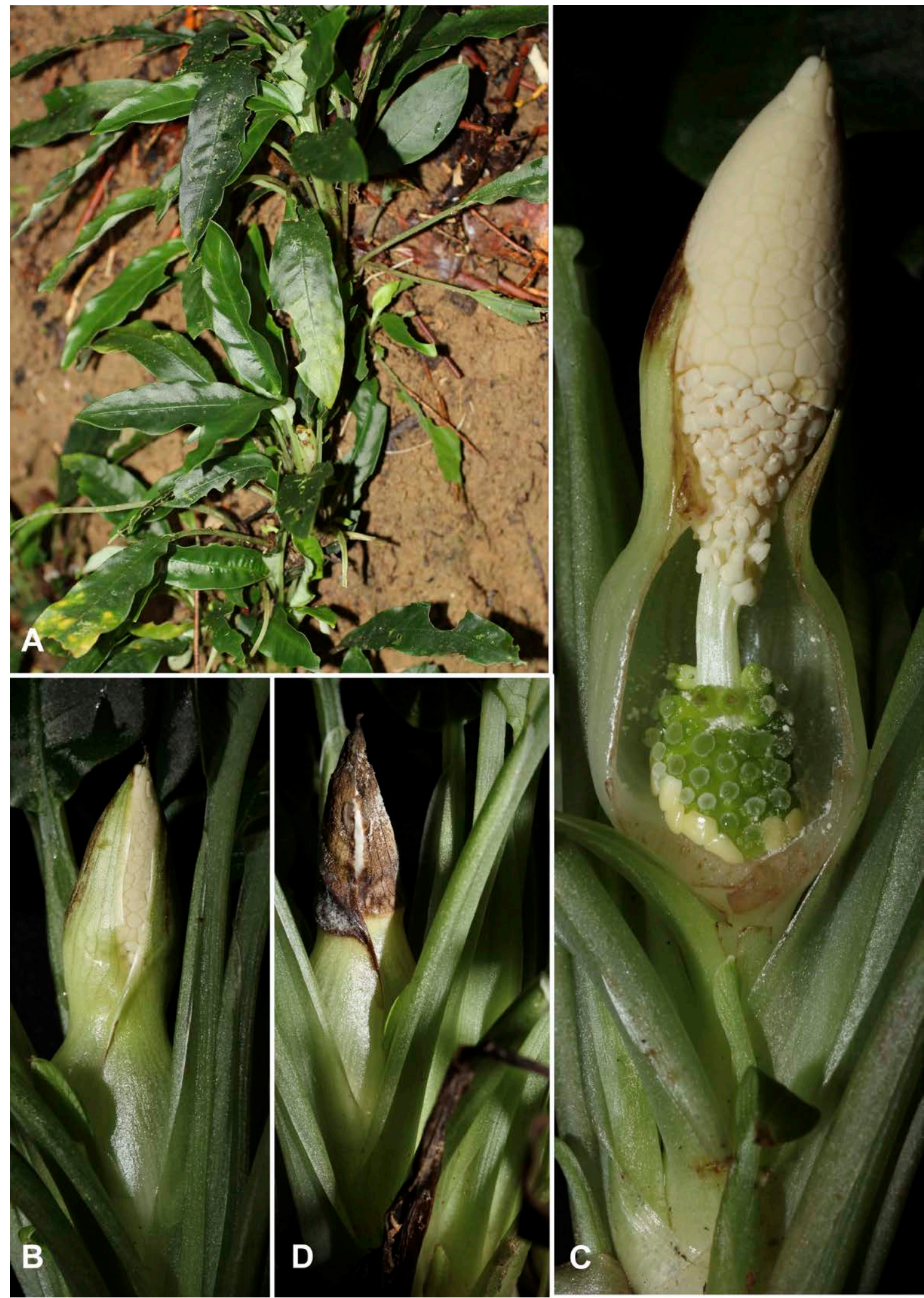

Figure 1. Schismatoglottis imbakensis (A) Plants in habitat. (B) Inflorescence at pistillate anthesis. The spathe limb slightly open. (C) Spadix at pistillate anthesis with the spathe artificially remove (D) Inflorescence staminate anthesis. The spathe limb darkening and rotting. 

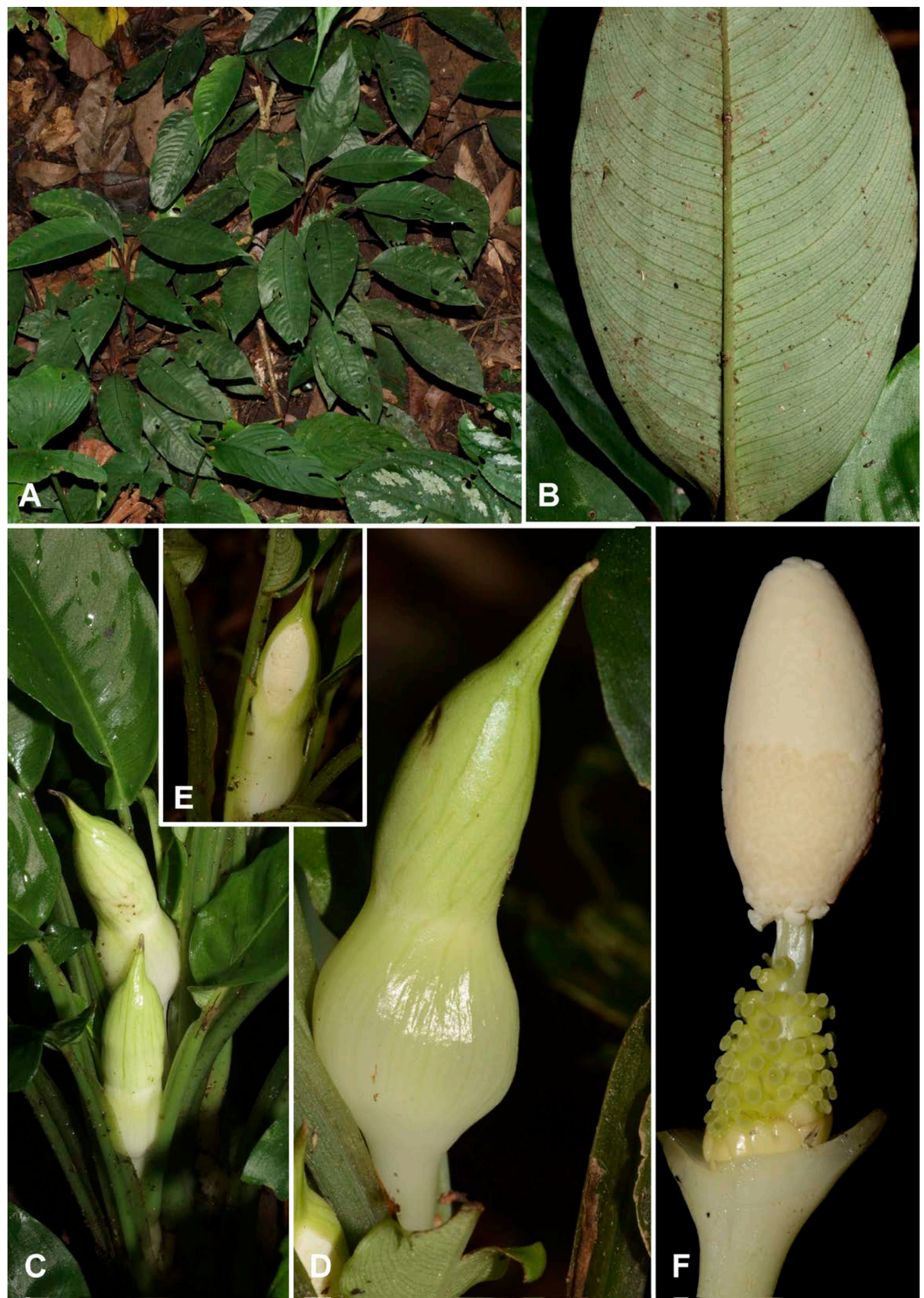

Figure 2. Schismatoglottis retinervia (A) Plants in habitat. (B) Leaf blade, abaxial view, showing the typical venation of species of the Schismatoglottis Patentinervia Clade. (C) Flowering shoots. (D \& E) Inflorescence at pistillate anthesis; note that the spathe limb hardly opens. (F) Spadix at pistillate anthesis, spathe artificially removed. A \& B from AR-4691; C - F from AR-4714. 


\section{Etymology}

The trivial epithet is from the Type locality plus the suffix -ensis, indicating 'from'.

\section{Distribution}

Known only from the type locality on the Sungai Kangkawat, Imbak Canyon Conservation Area.

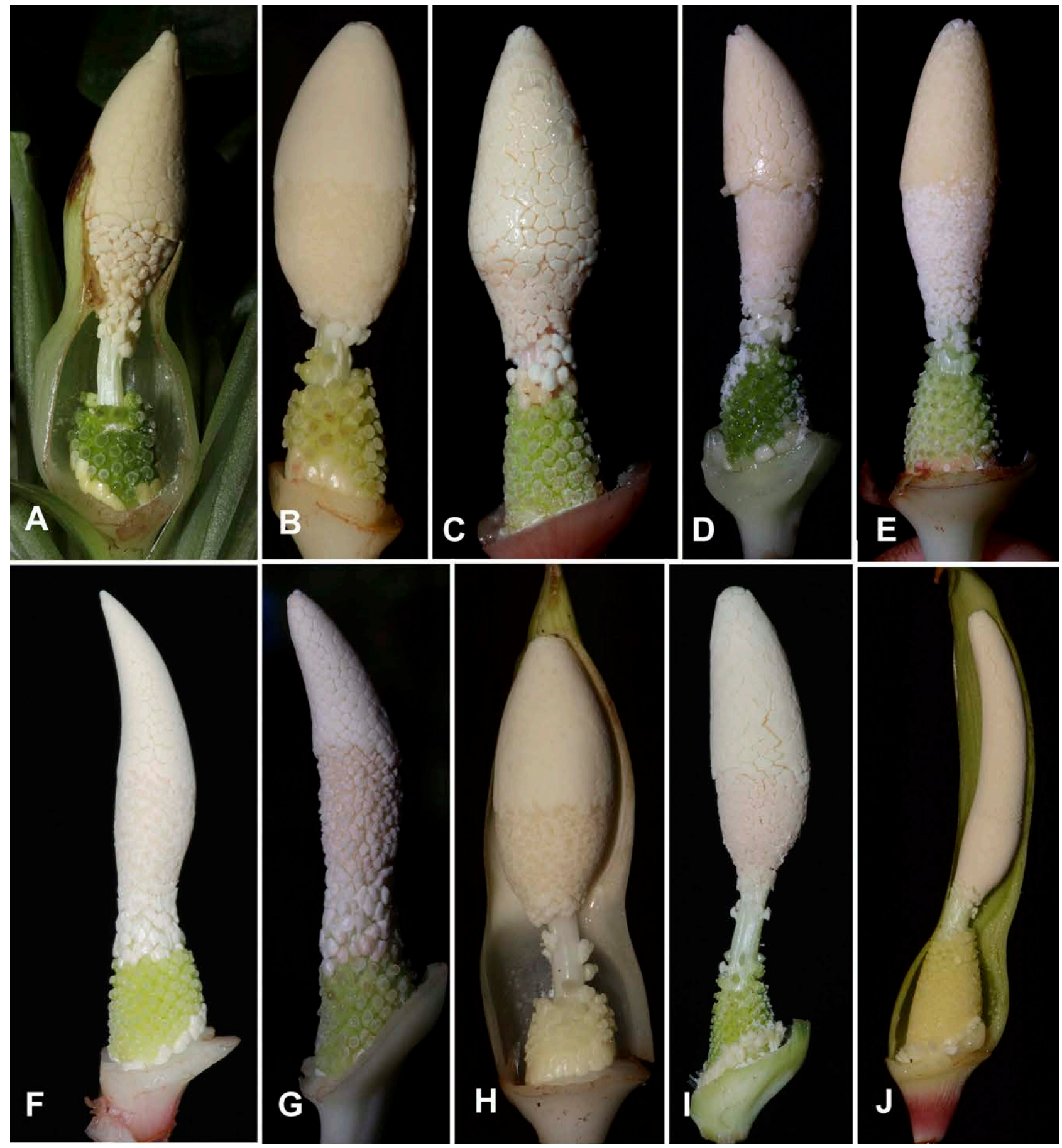

Figure 3. Spadices of 10 species of Schismatoglottis Patentinervia Clade compared. (A) Schismatoglottis imbakensis. (B) Schismatoglottis retinervia. (C) Schismatoglottis gangsai. (D) Schismatoglottis smaragdina. (E) Schismatoglottis fossae. (F) Schismatoglottis belonis. (G) Schismatoglottis gephyra (H) Schismatoglottis puncakborneensis. (I) Schismatoglottis pichinensis. (J) Schismatoglottis gaesa. 


\section{Ecology}

Primary lowland mixed dipterocarp forest on Cretaceous Harzburgite and Serpentinite outcrops, occurring on steep muddy river banks above the flood zone, about $270 \mathrm{~m}$ asl.

\section{Notes}

In Sabah Schismatoglottis imbakensis can be mistaken for $S$. retinervia, a species endemic to much higher altitude forest on granite in the Kinabalu area. The two species are readily separated as per the above diagnosis (Fig 1, 2, and 3A, 3B). The stoutly club-like spadix of Schismatoglottis imbakensis is most similar to that of $S$. gangsai S. Y. Wong, Aisahtul \& P. C. Boyce (Fig. 3C) and S. smaragdina S. Y. Wong, Aisahtul \& P. C. Boyce (Fig. 3D), both from Pelagus, Kapit, Sarawak, to S. fossae S. Y. Wong, Aisahtul \& P. C. Boyce (Sarawak: Mulu N.P. - Fig. 3E), S. puncakborneensis P. C. Boyce (Sarawak: Kuching, Penrissen Range - Fig. $3 \mathrm{H}$ ), and to S. pichinensis $\mathrm{P}$. C. Boyce (Sarawak: Serian, Padawan karst - Fig. 3I). Recognition of Schismatoglottis imbakensis takes the aroid flora of ultramafic substrates in Sabah to six species in four genera - Alocasia melo A. Hay, P. C. Boyce \& K. M. Wong, Bucephalandra ultramafica S. Y. Wong \& P. C. Boyce, Schismatoglottis (S. decipiens A. Hay, S. imbakensis, and S. silamensis A. Hay), and Tawaia sabahensis (S.Y. Wong, S.L. Low \& P.C. Boyce) S.Y. Wong \& P.C. Boyce. All are restricted to the substrate and furthermore locally endemic.

\section{ACKNOWLEDGEMENTS}

This study was carried out under Sabah Biodiversity Council Access License JKM/MBS.1000-2/1JLD.3(246), and is a collaboration between Universiti Malaysia Sabah and the Sabah Foundation. The second author extends thanks to Tan Sri Datuk Amar Leonard Linggi Anak Jugah and Malesiana Tropicals Sdn Bhd for continued support and encouragement.

\section{REFERENCES}

Boyce PC 2017. Studies on Schismatoglottideae (Araceae) of Borneo LXIII: Three new species for the Schismatoglottis Patentinervia Clade. Borneo Journal of Resource Science and Technology 7(2): 84-92.

Furtado CX. 1935. Araceae Malesicae. The Gardens' Bulletin, Straits Settlements 8: 145-158.

Oldfield M. 2014. The Green Heart of Sabah. Scubazoo Publications. 255pp.
Tate RB. 2001. The geology of Borneo island CDROM. Kuala Lumpur: Persatuan Geologi Malaysia / Geological Society of Malaysia.

Wong SY, Aisahtul binti W, Boyce PC. 2017. Studies on Schismatoglottis (Araceae) of Borneo LX: Preliminary notes on the Schismatoglottis Patentinervia Clade, including descriptions of three new species. Aroideana 40(1): 4-28.

Wong SY, Aisahtul binti W, Boyce PC. 2018. Studies on Schismatoglottis (Araceae) of Borneo LXIV: Another new species for Schismatoglottis Patentinervia Clade from the Rejang Basin, Sarawak. Aroideana 41(1): 139-148.

Wong SY, Boyce PC, Aisahtul binti Wardi, Chai SK. 2019. Araceae of Mulu National Park I: Four new species of Schismatoglottis (Araceae). Nordic Journal of Botany 37: doi 10.1111/njb.02566. 